УДК 635.21:631.5(292.485)(045)

(C) 2017

М'ялковський Р. О., кандидат сільськогосподарських наук, докторант

Подільський державний аграрно-технічний університет

\title{
ВПЛИВ ДОБРИВ НА ПРОДУКТИВНІСТЬ БУЛЬБ КАРТОПЛІ В УМОВАХ ПРАВОБЕРЕЖНОГО ЛІСОСТЕПУ УКРАЇНИ
}

\section{Рецензент - доктор сільськогосподарських наук В. І. Овчарук}

Досліджено вплив добрив на продуктивність бульб картоплі в умовах Правобережного Лісостепу Украӥни. Встановлено, щчо найвищу масу бульб отримали від сумісного внесення органічних $і$ мінеральних добрив 3 нормою фон $+N_{120} P_{120} K_{120}$ у середньостиглих сортів 616 г. Високою врожайністю бульб картоплі характеризувалися середньостиглі сорти (Віра, Слов'янка, Надійна), при изому найвищу врожайність встановлено у варіанті $\left(\right.$ фон $\left.+N_{120} P_{120} K_{120}\right)-38,8 \mathrm{~m} / 2$. Біохімічними аналізами встановлено, щзо вміст крохмалю в бульбах картоплі залежала від сорту та фону живлення, при изьому найвищий показник становив 17,2\% у варіанті (без добрив).

Ключові слова: картопля, сорт, трунт, мінеральні добрива, елементи живлення, урожай.

Постановка проблеми. Вирішальне значення у відтворенні та підвищенні родючості грунтів, одержанні високих урожаїв сільськогосподарських культур належить застосуванню мінеральних і органічних добрив [8].

Ефективність застосування добрив на посівах картоплі в різних агрокліматичних зонах значно різниться. Цими дослідженнями встановлено збільшення показників елементів продуктивності та урожайності досліджуваних сортів під впливом добрив. Проте в залежності від погодно-кліматичних умов, оптимальні дози внесення добрив різняться. Тому питання ефективності застосування добрив в умовах Правобережного Лісостепу України потребує конкретного вивчення.

Аналіз останніх досліджень і публікацій, у яких започатковано розв'язання проблеми. Головним критерієм управління урожайністю i якістю $є$ оптимізація живлення рослин. 3 метою одержання високоякісної продукції, в основу якої покладено принцип комфортності живлення, тобто створення таких умов, які забезпечують відсутність стресів у рослин від нестачі елементів живлення, позиційну доступність їх кореневій системі, пролонгованість дії добрив за оптимального забезпечення рослин іншими факторами середовища. На частку добрив, за оптимальних умов, припадає до $35-50 \%$ загального приросту врожаю [5].
Ю. В. Федорук, М. Я. Молоцький рекомендують середні норми гною під картоплю на дерново-підзолистих і опідзолених грунтах Полісся 50-60 т/га, в районах стійкого зволоження Лісостепу - 40-50 т/га, недостатнього зволоження $20-25$ т/га [7].

За вирощування картоплі на темно-сірих опідзолених грунтах Західного Лісостепу після пшениці озимої рекомендують вносити мінеральні добрива в нормі $\mathrm{N}_{85} \mathrm{P}_{60} \mathrm{~K}_{105}$ на фоні 40 т/га гною [6].

За даними I. М. Гнатюка [2] в умовах західного Лісостепу України найбільшу врожайність бульб по сортам Мавка і Луговська (342 i 412 ц/га) одержано в разі садіння за схемою $70 \times 20$ см і внесення 50 т/га гною $+\mathrm{N}_{90} \mathrm{P}_{90} \mathrm{~K}_{90}$. Найбільший вплив на приріст врожаю справляли добрива - 42,2 \% по сорту Мавка та 54,7 \% по сорту Луговська.

Найвищі врожаї картоплі вирощують за поєднаного внесення органічних і мінеральних добрив. Орієнтовні норми мінеральних добрив, які рекомендується вносити під картоплю (кг/га) 3 урахуванням грунтово-кліматичних умов на фоні органічних, так і на дерново-підзолистих, сірих лісових суглинкових грунтах $-\mathrm{N}_{90} \mathrm{P}_{70} \mathrm{~K}_{120}$, дерново-карбонатних - $\mathrm{N}_{90} \mathrm{P}_{60} \mathrm{~K}_{120}$, чорноземах типових $-\mathrm{N}_{45} \mathrm{P}_{60} \mathrm{~K}_{60}[3]$.

Виходячи 3 вищевикладеного, видно, що ефективність виробництва картоплі досить сильно залежить від внесення добрив.

Метою дослідження було вивчення впливу добрив на ріст і продуктивність різних за стиглістю сортів картоплі в умовах Правобережного Лісостепу України.

Матеріал і методи досліджень. Дослідження проводились на дослідному полі Навчальновиробничого центру «Поділля» Подільського державного аграрно-технічного університету протягом 2015-2017 років.

Грунт дослідного поля - чорнозем типовий вилугуваний, мало гумусний, середньо суглинковий на лесовидних суглинках. Вміст гумусу (за Тюріним) в шарі грунту $0-3 \mathrm{~cm}$ становить $3,6-4,2 \%$. Вміст сполук азоту, що легко гідролі- 


\section{СІЛЬСЬКЕ ГОСПОДАРСТВО. РОСЛИННИЦТВО}

зуються (за Корнфілдом) становить 98-139 мг/кг (високий), рухомого фосфору (за Чіріковим) 143-185 мг/кг (високий) i обмінного калію (за Чіріковим) - 153-185 мг/кг грунту (високий). Сума увібраних основ коливається в межах 158209 мг екв./кг. Гідролітична кислотність становить 17-22 мг екв./кг, ступінь насичення основами $-90 \%$.

Клімат - помірно континентальний. Середньорічна температура повітря становить $7,8{ }^{\circ} \mathrm{C}$. Зими Правобережного Лісостепу малосніжні, 3 частими відлигами. Середня тривалість безморозного періоду становить від 117 до 136 діб. Перехід середньодобової температури повітря через $10{ }^{\circ} \mathrm{C}$ навесні припадає на третю декаду квітня. Закінчення цих температур спостерігається в першій декаді жовтня. Період із середньодобовою температурою вище $10{ }^{\circ} \mathrm{C}$ триває в середньому 160-165 днів. Сума активних температур становить $2765^{\circ} \mathrm{C}$. Гідротермічний коефіцієнт в регіоні становить 1,4. Кількість опадів та зволоження найменші в області і коливаються в межах 620 мм, хоча здебільшого вони оптимальні для розвитку рослин.

Вивчення впливу добрив на ріст і продуктивність різних за стиглістю сортів картоплі.

Фактор A - добрива: I варіант - без добрив (контроль); II варіант - 40 т/га гною (фон);

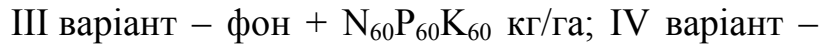

фон $+\mathrm{N}_{90} \mathrm{P}_{90} \mathrm{~K}_{90}$ кг/га; 5 - фон $+\mathrm{N}_{120} \mathrm{P}_{120} \mathrm{~K}_{120}$ кг/га.

Фактор В - сорти: середньоранні - Диво (контроль), Легенда, Малинська біла; середньостиглі - Віра, Слов'янка (контроль), Надійна; середньопізні - Оксамит (контроль), Алладін, Дар.

Площа облікової ділянки під добривами становила $450 \mathrm{~m}^{2}$, під сортом картоплі $50 \mathrm{~m}^{2}$, повторність - чотириразова.

Фенологічні спостереження, біометричні і фізіолого-біохімічні дослідження проводили за методиками Г. Л. Бондаренка, К. І. Яковенка, В. Ф. Мойсейченка $[1,4]$.

Результати досліджень показують, що сумісне застосування органічних і мінеральних добрив сприяє підвищенню інтенсивності росту i підвищення врожаю бульб картоплі (див. табл.).

Важливим елементом у структурі врожаю $\epsilon$ маса бульб у фазі технічної стиглості, яка на різних сортах варіювала в дуже значних межах від 423 до 616 г. Найвищу масу бульб отримали від сумісного внесення органічних і мінеральних добрив 3 нормою фон $+\mathrm{N}_{120} \mathrm{P}_{120} \mathrm{~K}_{120}$ у сортів різних груп стиглості. у середньостиглих сортів маса бульб в середньому за три роки досліджень становила у варіанті 40 т/га гною (фон) - 498 г, фон $+\mathrm{N}_{60} \mathrm{P}_{60} \mathrm{~K}_{60}-544$ г, фон $+\mathrm{N}_{90} \mathrm{P}_{90} \mathrm{~K}_{90}-593$ г, фон $+\mathrm{N}_{120} \mathrm{P}_{120} \mathrm{~K}_{120}-616$ г. На контрольному варіанті (без добрив) середня маса бульб у фазу технічної стиглості становила 464 г.

Вилив добрив на продуктивність бульб картоплі (середнс за 2015-2017 рр.)

\begin{tabular}{|c|c|c|c|c|c|c|c|}
\hline \multirow[b]{2}{*}{ Добрива } & \multicolumn{3}{|c|}{ Середня маса, г } & \multirow[b]{2}{*}{$\begin{array}{c}\text { Крохмаль, } \\
\text { \% }\end{array}$} & \multicolumn{2}{|c|}{ Урожай, т/га } & \multirow{2}{*}{$\begin{array}{c}\text { Прибавка } \\
\text { врожаю } \\
\text { бульб, т/га }\end{array}$} \\
\hline & $\begin{array}{c}\text { всієї } \\
\text { росли- } \\
\text { ни } \\
\end{array}$ & бульб & бадилля & & бульб & крохмалю & \\
\hline \multicolumn{8}{|c|}{ середньоранні сорти (середнє) } \\
\hline Без добрив (к*) & 934 & 455 & 47,9 & 16,8 & 28,6 & 1,7 & - \\
\hline 40 т/га гною (фон) & 978 & 493 & 485 & 16,4 & 31,0 & 1,8 & 2,4 \\
\hline$\phi \mathrm{\phi H}+\mathrm{N}_{60} \mathrm{P}_{60} \mathrm{~K}_{60}$ & 1052 & 529 & 523 & 15,7 & 33,3 & 2,1 & 4,7 \\
\hline фон $+\mathrm{N}_{90} \mathrm{P}_{90} \mathrm{~K}_{90}$ & 1108 & 588 & 520 & 14,8 & 37,0 & 2,5 & 8,4 \\
\hline фон $+\mathrm{N}_{120} \mathrm{P}_{120} \mathrm{~K}_{120}$ & 1216 & 614 & 602 & 14,7 & 38,6 & 2,6 & 10,0 \\
\hline \multicolumn{8}{|c|}{ середньостиглі сорти (середнє) } \\
\hline Без добрив (к*) & 976 & 464 & 512 & 17,2 & 29,2 & 1,6 & - \\
\hline 40 т/га гною (фон) & 1034 & 498 & 536 & 16,7 & 31,3 & 1,8 & 2,1 \\
\hline$\phi о \mathrm{H}+\mathrm{N}_{60} \mathrm{P}_{60} \mathrm{~K}_{60}$ & 1100 & 544 & 556 & 15,8 & 34,2 & 2,1 & 5,0 \\
\hline фон $+\mathrm{N}_{90} \mathrm{P}_{90} \mathrm{~K}_{90}$ & 1201 & 593 & 608 & 15,1 & 37,3 & 2,4 & 8,1 \\
\hline$\phi о \mathrm{H}+\mathrm{N}_{120} \mathrm{P}_{120} \mathrm{~K}_{120}$ & 1371 & 616 & 755 & 14,9 & 38,8 & 2,6 & 9,6 \\
\hline \multicolumn{8}{|c|}{ середньопізні сорти (середнє) } \\
\hline Без добрив (к*) & 837 & 423 & 414 & 16,4 & 26,6 & 1,6 & - \\
\hline 40 т/га гною (фон) & 1064 & 474 & 510 & 15,7 & 29,8 & 1,8 & 3,2 \\
\hline фон $+\mathrm{N}_{60} \mathrm{P}_{60} \mathrm{~K}_{60}$ & 1293 & 492 & 700 & 15,0 & 30,9 & 2,0 & 4,3 \\
\hline фон $+\mathrm{N}_{90} \mathrm{P}_{90} \mathrm{~K}_{90}$ & 1472 & 553 & 719 & 14,1 & 34,8 & 2,4 & 8,2 \\
\hline$\phi о \mathrm{H}+\mathrm{N}_{120} \mathrm{P}_{120} \mathrm{~K}_{120}$ & 1609 & 598 & 811 & 14,7 & 37,6 & 2,5 & 10,0 \\
\hline
\end{tabular}

Примітка: $\left(\mathrm{\kappa}^{*}\right)-$ контроль. 


\section{СІЛЬСЬКЕ ГОСПОДАРСТВО. РОСЛИННИЦТВО}

Як свідчать результати наших досліджень, вміст крохмалю залежав від біологічних особливостей сортів і варіював у межах 14,1-17,2 \%.

Аналіз біохімічних показників бульб свідчить, що у фазу технічної стиглості найвищим вмістом крохмалю в середньому за три роки відзначались середньостиглі сорти. Так у варіанті 40 т/га гною (фон) вміст крохмалю становив 16,7\%, фон + N60P60K60 - 15,8 \%, фон $+\mathrm{N}_{90} \mathrm{P}_{90} \mathrm{~K}_{90}-15,1 \%$, фон $+\mathrm{N}_{120} \mathrm{P}_{120} \mathrm{~K}_{120}-14,9 \%$. на контрольному варіанті (без добрив) цей показник становив $(17,2 \%)$. Таким чином 3 вище викладеного матеріалу можна зробити висновок, що застосування органічних та мінеральних добрив призводить до зменшення вмісту крохмалю у бульбах картоплі в усіх досліджуваних сортів.

Із внесенням тільки органічних добрив (40 т/га гною) для всіх сортів різної стиглості дало прибавку врожаю середньоранніх сортів - 2,4 т/га, середньостиглих - 2,1 т/га і середньопізніх сортів - 3,2 т/га. Тоді як сумісне внесення органічних i мінеральних добрив 3 нормою фон + $\mathrm{N}_{120} \mathrm{P}_{120} \mathrm{~K}_{120}$ дало прибавку врожаю середньоранніх сортів - 10,0 т/га, середньостиглих - 9,6 т/га i середньопізніх сортів - 10,0 т/га. Зі збільшенням норми мінеральних добрив, за достатньої вологості грунту збільшується як інтенсивність росту, так і врожай бульб картоплі. Внаслідок сумісного застосування органічних i мінеральних добрив є одним із головних показників підвищення врожаю продуктивності рослин картоплі,

\section{БІБЛІОГРАФІЯ}

1. Бондаренко Г. Л. Методика дослідної справи в овочівництві і баштанництві / Г. Л. Бондаренко, К. І. Яковенко. - Х. : Основа, 2001. -370 c.

2. Гнатюк I. M. Залежність урожаю та якості картоплі від схем садіння, норм добрив і маси садивних бульб в умовах західного Лісостепу України [Текст] : автореф. дис. к. с.-г. н. : 06.01.09 / I. М. Гнатюк. - Інститут цукрових буряків УААН. - К., 1997. - 22 с.

3. Ільчук P. В. Урожайність картоплі залежно від рівнів живлення, способів внесення добрив та маси садивних фракцій / Р. В. Ільчук, Л. А. Ільчук, В. В. Альохін // Картоплярство України. - К., 2013. - №1-2 (32-33). - С. 24-27.

4. Моисейченко В. Ф. Основы научных исследований в агрономии / В.Ф. Моисейченко, М.Ф. Трифонова, А. Х. Завирюха. - М. : Колос, 1996. $-336 \mathrm{c}$. оскільки вони створюють найбільш сприятливі умови для живлення рослин протягом усього періоду вегетації.

В результаті вивчення впливу добрив на інтенсивність росту рослин картоплі встановлено, що ріст рослин більшій мірі залежить від забезпеченості їх поживними речовинами, від концентрації і співвідношення основних елементів живлення картоплі.

Поживні речовини у виробничих посівах, в умовах Правобережного Лісостепу України, в більшості випадків знаходяться в мінімумі для процесів росту в порівнянні з іншими факторами зовнішнього середовища. Тому, покращання умов живлення азотом і зольними елементами, шляхом правильного застосування добрив, представляє собою один із найбільш потужних факторів підвищення інтенсивності росту і врожаю картоплі.

Висновок. Встановлено, що високою врожайністю бульб картоплі характеризувалися середньостиглі сорти (Віра, Слов'янка, Надійна), при цьому найвищу врожайність встановлено у варіанті (фон $\left.+\mathrm{N}_{120} \mathrm{P}_{120} \mathrm{~K}_{120}\right)-38,8$ т/га. Біохімічними аналізами встановлено, що вміст крохмалю в бульбах картоплі залежала від сорту та фону живлення. так, найвищий цей показник становив 17,2 \% у варіанті (без добрив). Таким чином, застосування органічних та мінеральних добрив призводить до зменшення вмісту крохмалю у бульбах картоплі в усіх досліджуваних сортів.

5. Потапенко Л. В. Агрохімічна оцінка різних систем удобрення картоплі при вирощуванні в зоні Полісся / Л. В. Потапенко // Картоплярство: міжвід. темат наук. збірн. - К. : Аграрна наука, 2014. - Вип. 42. - С. 175-184.

6. Семенчук В. Г. Продуктивність сортів картоплі в умовах Південно-Західної частини України / В. Г. Семенчук // Картоплярство України. Наук. вироб. журнал. - К. : ТОВ «Інфо-принт», 2014. - №1-2 (34-35). - С. 39-41.

7. Федорук Ю. В. Зміна біохімічного складу бульб картоплі залежно від сорту і добрив в умовах Центрального Лісостепу України / Ю. В. Федорук, М. Я. Молоцький // Картоплярство: міжвід. темат. наук. зб. - К. : Аграрна наука, 2008. - Вип. 37. - С. 194-212.

8. Чекмарев П. А. Удобрения, урожай и качество клубней / П. А. Чекмарев // Картофель и овощи. - М. : Колос, 2006. - №8. - С. 10. 